\title{
Peran Lembaga Pendidikan Sekkau Dalam Menyiapkan Peserta Didik Profesional Di Era Society 5.0
}

\section{(The Role Of Sekkau Education Institutions In Preparing Professional Students In The Society 5.0 Era)}

\author{
Hanny Christian Sahupala ${ }^{1,5}$, Jimmy Veni Tokio ${ }^{2,6}$, Linda Sartika ${ }^{3,7}$, Agus Pudjianto $^{4,8}$ \\ ${ }^{1,2,3}$ Sekolah Komando Kesatuan Angkatan Udara \\ E-mail: ${ }^{5}$ hannychristiansahupala704@gmail.com; ${ }^{6}$ jimmy_tokio@yahoo.com, \\ ${ }^{7}$ lindasartika05@gmail.com \\ ${ }^{4}$ Prodi Teknik Manajemen Industri Akademi Angkatan Udara \\ E-mail: ${ }^{8}$ agus_pudji@aau.ac.id
}

\begin{abstract}
The role of the Sekkau educational institution is to prepare various things that are included in the education component such as the readiness of educational facilities, the readiness to develop the existing curriculum, the readiness of human resource providers (HR), alins/alongin with a perspective on society 5.0, by improving the quality of student outcomes. superior ones who have future insights equipped with various developments such as the quality of human resources, curriculum development, and equipped with competency standards and innovations for lecturers to be able to improve the quality of students in educational learning. Furthermore, it produces several developments in the form of educational goals in line with educational goals and strategies that have been planned by carrying out various evaluations which include involving educational facilities (fasdik), girls (education staff), curriculum development and the condition of students who can attend education with psychological and mental qualities. physically healthy and able to understand every lesson provided by the institution. The Lecturer profession also makes changes both in analysis and application as well as innovations that can increase changes towards technological progress.
\end{abstract}

Keywords: Education, Serdik, Lecturer, Curriculum.

Abstrak----Peran lembaga pendidikan Sekkau adalah menyiapkan berbagai hal yang termasuk dalam komponen pendidikan seperti kesiapan fasilitas pendidikan, kesiapan pengembangan kurikulum yang ada, kesiapan penyelenggara sumber daya manusia (SDM), alins/alongin yang berperspektif pada society 5.0, dengan melakukan peningkatan terhadap kualitas hasil peserta didik yang unggul yang mempunyai wawasan kedepan dengan diperlengkapi berbagai pengembangan seperti kualitas SDM, pengembangan kurikulum, dan diperlengkapi oleh standar kompetensi dan inovasi bagi para dosen untuk dapat meningkatkan kualitas peserta didik dalam pembelajaran pendidikan. Selanjutnya menghasilkan beberapa pengembangan berupa tujuan pendidikan seiiring dengan sasaran dan startegi pendidikan yang telah direncanakan dengan melakukan berbagai evaluasi yang diantaranya melibatkan fasilitas pendidikan (fasdik), gadik (tenaga pendidikan), pengembangan kurikulum serta kondisi peserta didik yang dapat mengikuti pendidikan dengan kualitas mental psikologi dan fisik yang sehat serta dapat mengerti setiap pembelajaran yang diberikan oleh lembaga. Profesi Dosen juga melakukan perubahan baik dalam analisa maupun aplikasi serta inovasi-inovasi yang dapat meningkatkan perubahan kearah kemajuan teknologi.

Kata Kunci : Pendidikan, Serdik, Dosen, Kurikulum.

*Penulis Korespondensi (Hanny Christian)

E-mail: hannychristiansahupala704@gmail.com 


\section{PENDAHULUAN}

$\mathrm{D}$ atangnya era Society 5.0 membawa masyarakat untuk mampu menyelesaikan berbagai tuntutan dari tantangan yang datang melalui permasalahan sosial yang bermanfaat untuk mendukung keterlibatan berbagai inovasi revolusi industri 4.0 melalui Internet of Things (internet untuk segala sesuatu), Artificial Intelligence (kecerdasan buatan), Big Data (data dalam jumlah besar), dan penggunaan robot untuk meningkatkan kualitas hidup manusia sebagai bagian dari kemajuan teknologi, khususnya dalam pengerjaan kehidupan manusia yang didukung oleh sistem digitalisasi dalam mendukung program pendidikan saat ini. Program pengembangan Sumber Daya Manusia (SDM) dalam medukung Indonesia unggul menjadi pilar pembangunan nasional melalui sistem pendidikan dan pembinaan yang terintegrasi guna pemenuhan materi kuliah perwira siswa Sekkau seperti halnya penyelenggaraan program smart campus (society 5.0) yang dimiliki lembaga pendidikan Sekkau. Keunggulan ini berdampak pada pemikiran yang kritis, berjiwa aktual dan memiliki wawasan kedepan untuk kemajuan TNI AU dan kemajuan di dunia pendidikan pada umumnya.

Tantangan yang dihadapi dalam peran lembaga di Sekkau ini, meliputi kesiapan dalam berbagai hal yang termasuk dalam komponen pendidikan seperti kesiapan fasilitas pendidikan, kesiapan pengembangan kurikulum yang ada, kesiapan penyelenggara sumber daya manusia (SDM), alins/alongin yang berperspektif pada society 5.0, dan tahapan untuk meningkatkan kualitas hasil peserta didik yang unggul dan berwawasan kedepan.

Upaya peningkatan peran lembaga pendidikan ini diwujudkan dengan melakukan validasi organisasi di Sekkau yang telah dilaksanakan, sejauh ini postur dari proses belajar mengajar di Sekkau masih memiliki strategi peningkatan mutu yang tepat melalui konsep learning material provider, menyiapkan pendidik untuk menjadi inspirator tumbuhnya kreativitas peserta didik, memiliki peran pendidik sebagai fasilitator, tutor, dan motivator peserta didik guna meningkatkan mutu peserta didik. Dampak dari perkembangan ini menimbulkan peserta didik memiliki adaptasi dan kompetensi yang baik seiring adanya peningkatan standar mutu fasilitas pendidikan dan kurikulum khususnya dibidang operasi udara, kepemimpinan, dsb, sehingga lembaga Sekkau dapat memberikan lulusan yang berkualitas dan memberi dorongan bagi peningkatan kemajuan teknologi petahanan serta memiliki konsep yang strategis, unggul, dan memiliki peran penting dalam mendukung upaya kemandirian industri pertahanan nasional kedepan.

\section{LANDASAN TEORI}

Landasan dalam penulisan naskah ini menggunakan 3 (tiga) teori yang meliputi :

A. TEORI PENGEMBANGAN KURIKULUM. Pengembangan kurikulum menurut Robert M. Diamond (1989), dan sarjana lainnya, adalah pengembangan program dalam konteks pengembangan kurikulum akan berkenaan pada dua hal, yaitu: pengembangan suatu bidang studi/ mata kuliah/mata pelajaran (course); dan pengembangan kurikulum pendidikan secara menyeluruh (curriculum). Keduanya (course dan curriculum) memiliki kontribusi untuk saling berhubungan, saling mempengaruhi, dan saling bergantungan. Ada beberapa landasan utama dalam pengembangan suatu kurikulum, yaitu landasan filosofis, psikologis, sosial-budaya, serta perkembangan ilmu dan teknologi. Landasan tersebut dihasilkan melalui pemikiran dan penelitian yang bersifat mendalam dan komprehensif, yang pada hakikatnya berupa bahan pertimbangan terhadap faktor-faktor yang harus diperhatikan oleh para pengembang kurikulum dalam mengembangkan kurikulum pada lembaga pendidikan, baik secara makro maupun mikro. 


\section{B. TEORI SUMBER DAYA MANUSIA.}

Teori ini menurut Nawawi menerangkan 3 (tiga) pengertian tentang sumber daya manusia, yaitu :

1) Sumber Daya Manusia (SDM) adalah manusia yang bekerja di lingkungan suatu organisasi (disebut juga personil, tenaga kerja, pekerja, dan karyawan).

2) Sumber Daya Manusia (SDM) adalah potensi manusia sebagai penggerak organisasi dalam mewujudkan eksistensinya.

3) Sumber Daya Manusia (SDM) adalah potensi yang merupakan asset dan berfungsi sebagai model (non material/non financial) didalam organisasi bisnis, yang dapat diwujudkan menjadi potensi nyata (real) secara fisik dan non fisik dalam mewujudkan eksistensi organisasi.

4) Sumber Daya Manusia (SDM) adalah individu yang bekerja dan menjadi anggota suatu perusahaan atau institusi dan biasa disebut sebagai pegawai, buruh, karyawan, pekerja, tenaga kerja dan lain sebagainya. Sedangkang pengertian SDM secara makro adalah penduduk suatu negara yang sudah memasuki usia angkatan kerja, baik yang belum bekerja maupun yang sudah bekerja.

\section{TEORI KOMPONEN PENDIDIKAN.}

1) Komponen memegang peranan penting dalam proses pendidikan, karena saling berinteraksi antar satu dengan lainnya. Terkait hal tersebut sebagai penentu kesuksesan dari pendidikan adalah penerapan sepuluh komponen pendidikan yang meliputi: kurikulum pendidikan, paket instruksi, tenaga pendidik, tenaga kependidikan, peserta didik, alins/alongins, fasilitas pendidikan, metode, evaluasi hasil belajar dan anggaran pendidikan

2) Komponen pendidikan menurut PH. Coombs menentukan pendiidikan ada 12 komponen, namun yang paling menonjol adalah pentingnya peran teknologi yang dihadirkan dalam proses belajar mengajar yang sukses untuk menuju society 5.0. Adapun kedua belas komponen itu antara lain: tujuan dan priorotas, peserta didik, manajemen, struktur dan jadwal waktu, isi atau materi, dosen dan pelaksana, alat dan sumber belajar, fasilitas, teknologi, pengawasan mutu, penelitian, biaya pendidikan.

\section{MODEL WEB BASE/ELECTRONIC LEARNING DI ERA 5.0}

Teknologi Informasi (TI) telah memberikan sejumlah dampak positif di berbagai bidang (Abdillah et al., 2020). Pada dunia bidang pendidikan, TI memberikan corak tersendiri dengan berbagai mode yang mungkin digunakan. Pendidikan modern di masa globalisasi dan berbasis Teknologi Informasi telah bertransformasi ke arah digital. TI telah menjadi tulang punggung proses pembelajaran modern (Abdillah et al., 2021). Proses pendidikan yang tadinya dilakukan secara klasik dengan mode tatap muka secara langsung telah mengalami pergeseran ke arah mode pembelajaran jarak jauh (distance learning). Pada mode pembelajaran ini, para peserta didik dapat mengakses materi perkuliahan melalui internet. Hal ini telah dilakukan oleh Sekkau saat banyaknya perwira siswa yang mengalami penyakit Covid-19. Sistem ini telah menjadi aturan dari Diskes TNI AU. 


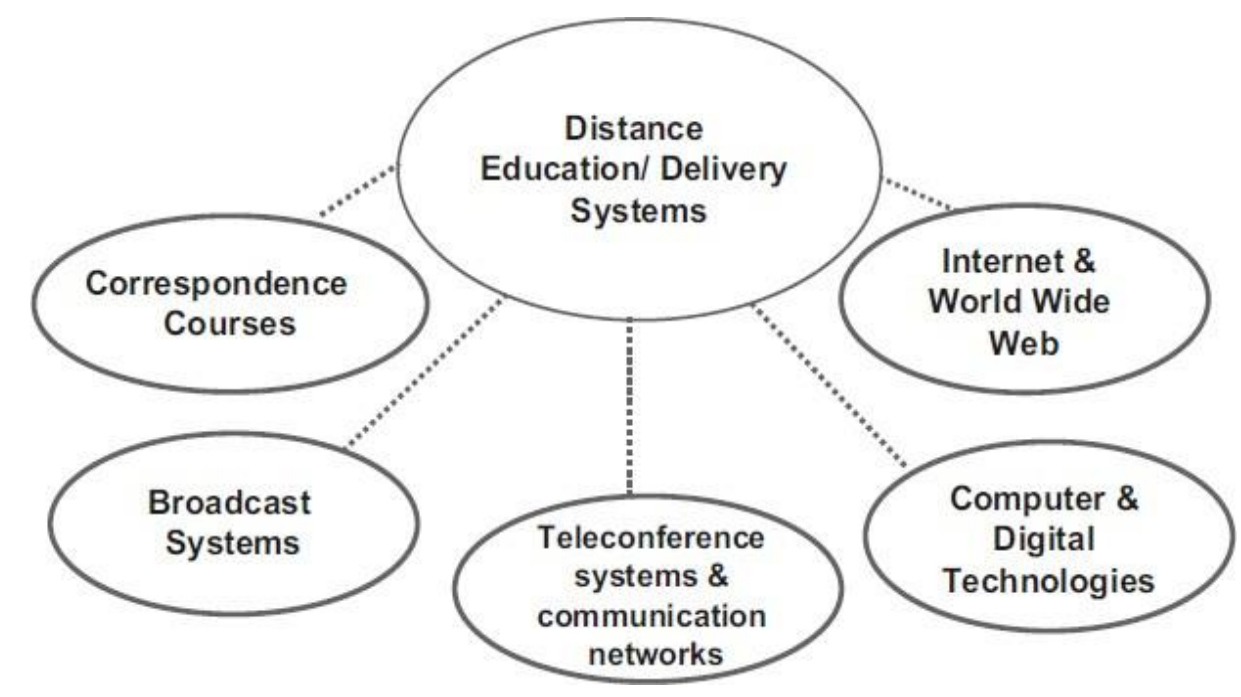

Gambar 1. Tipe Model Sistem

Distance Education (Davidson-Shivers, Rasmussen and Lowenthal, 2018)

E-learning merupakan pembelajaran jarak jauh yang menggunakan teknologi komputer atau biasanya disebut internet. E-learning sebagai kegiatan belajar yang disampaikan melalui perangkat elektronik komputer yang memperoleh bahan belajar yang sesuai dengan kebutuhannya. E-learning merubah model pembelajaran tradisional menjadi visual dan tanpa tatap muka. Para dosen dapat menyediakan bahan-bahan pelajaran untuk peserta didik (siswa), mengontrol materi yang diajarkan, mengeksplorasi kegiatan masing-masing peserta seperti absensi online, pengumpulan tugas, dan lainlain. Terlebih lagi juga dosen dapat mengatur chat online dengan peserta, mengumumkan beberapa informasi, dan memberikan masukan berharga bagi siswanya (Abdillah, 2013). Kegiatan ini telah dilakukan melalui zoom, Program LMS, evaluasi melalui aplikasi google dan berbagai kegiatan daring baik selama kegiatan Covid-19 melanda maupun ketika peserta didik melakukan pendidikan di rumah.

\section{IMPLEMENTASI PERAN LEMBAGA PENDIDIKAN}

Penulisan naskah ini memuat tentang peran lembaga pendidikan Sekkau dalam menyiapkan peserta didik profesional di era society 5.0, yang merupakan bagian dari pelaksanaan kegiatan pendidikan dan pengajaran lembaga pendidikan yang berada di bawah Kodiklatau dalam menyelenggarakan pendidikan dan pengembangan umum untuk tingkat pertama bagi perwira TNI/TNI AU yang memiliki tujuan untuk mengembangkan dan meningkatkan kemampuan perwira TNI AU terpilih agar dapat memiliki kemampuan taktis, teknis, dan administratif, serta kesegaran jasmani yang baik, sehingga dapat menjadi pelaksana kegiatan yang siap operasional, memiliki motivasi dan dedikasi yang tinggi, serta penguasaan terhadap ilmu pengetahuan yang didukung dengan keterampilan teknis, tingkat tertentu pada kecabangan/korps/fungsi angkatan sehingga memiiki karakter untuk menjadi prajurit Pancasila, Saptamarga, Sumpah Prajurit dan Delapan Wajib TNI.

Adapun penyelenggaraan ini membutuhkan berbagai aspek yang dapat mendukung bagi terlaksananya perencanaan dengan benar, melalui penggunaan strategi dan sasaran pendidikan 
yang memenuhi target pengajaran yang sesuai dengan taraf pendidikan tertentu. Proses perencanaan yang dilakukan dalam pendidikan kedinasan dalam menunjang karier yang dibuat lembaga kedinasan TNI yang memiliki sejumlah strategi dan sasaran pendidikan yang dikembangkan melalui jenjang pendidikan lanjutan bagi kebutuhan karier di lingkungan TNI AU dengan perencanaan sebagai berikut:

\section{A. Startegi dan Tujuan dan Sasaran Pendidikan.}

1. Strategi Pendidikan Sekkau. Pengertian strategi merupakan upaya yang sistematis untuk mencapai tujuan yang telah ditetapkan melalui pencapaian sasaransasaran dari tujuan tersebut. Strategi ini menjelaskan tentang komponen-komponen yang harus disiapkan untuk mencapai sasaran dari tujuan dengan tiap-tiap komponen yang memiliki berbagai program yang dilaksanakan dengan fokus program untuk mendukung pendidikan dan pengajaran, selain itu adanya program penelitian khususnya tentang permasalahan yang menonjol saat ini, diantaranya pelaksanaan seminar yang bertemakan covid 19, dsb dengan penilaian dari berbagai aspek pendukungnya), dan program kerjasama dalam pola pengajaran dan pengembangan kualitas pendidikan dengan Kodiklatau, Seskoau dan Sesko TNI serta beberapa perguruan tinggi di Jakarta seperti pengetahuan tentang operasi udara dan operasi gabungan, intelijen leadership, serta pengenalan mata pelajaran umum lainnya.

2. Tujuan Pendidikan Sekkau. Sesuai dengan amanat perundangan bahwa Tujuan Pendidikan Nasional berbunyi "Pendidikan nasional bertujuan untuk mengembangkan potensi peserta didik agar menjadi manusia yang beriman dan bertakwa kepada Tuhan Yang Maha Esa, berakhlak mulia, sehat, berilmu, cakap, kreatif, mandiri, dan menjadi warga negara yang demokratis serta bertanggung jawab." Dengan tujuan pendidikan nasional ini, maka bagi pendidikan TNI dengan strata perwira pertama maka melalui Juknis Opsdik menerangkan bahwa Pendidikan Sekkau bertujuan untuk mendidik dan membekali perwira TNI Angkatan Udara sebagai prajurit Sapta Marga yang memiliki jiwa kepemimpinan, menejerial staf, pengetahuan dan keterampilan taktis maupun teknis matra udara, serta kesegaran jasmani yang baik sehingga mampu melaksanakan tugas perwira staf dan komando yang profesional pada golongan jabatan VI.

3. Sasaran Pendidikan Sekkau. Sasaran Pendidikan Sekkau dalam kurikulum yang telah dibuat adalah mewujudkan siswa yang memiliki:

a) Karakter sebagai prajurit Pancasila, Saptamarga, Sumpah Prajurit, dan Delapan Wajib TNI dalam setiap pelaksanaan tugasnya.

b) Dasar keilmuan, pengetahuan dan wawasan tentang kepemimpinan, manajemen staf, dan administratif baik taktis ataupun teknis operasional matra udara.

c) Keterampilan umum dan khusus dalam mengaplikasikan kepemimpinan, manajemen staf, dan administratif baik taktis ataupun teknis operasional matra udara.

d) Kesegaran jasmani yang baik.

Berdasarkan perwujudan tentang isi Undang-Undang Nomor 20 Tahun 2003 tentang Sistem Pendidikan Nasional ini, memberikan fokus tentang sasaran pendidkan yang memiliki fungsi dalam pengembangan kemampuan dan watak bagi suatu bangsa yang dipengaruhi oleh nilai kehormatan dalam pencapaian kecerdasan bangsa untuk tujuan pengembangkan potensi yang dimiliki peserta didik sehingga dapat memiliki iman dan taqwa kepada Tuhan Yang Maha Esa, berakhlak budi yang mulia, serta memiliki kesehatan yang baik untuk jiwa dan raga. Demikian pula untuk kemampuan pengetahuan hendaknya memiliki kecakapan yang tinggi, 
memiliki daya kreatifitas yang diatas rata-rata, berupaya untuk meningkatkan kemandirian, dan menjadikan pribadinya sebagai bagian dari warga negara yang rasa nasionalisme dan demokratis sebagai warga negara Indonesia serta bertingkah laku yang baik, sopan serta memiliki intergrtas dan bertanggung jawab dalam berbagai aspek pengembangan diri untuk menjadikan pribadi yang sesuai dengan tujuan nasional.

Beberapa hal yang berkaitan dengan pendidikan di era 5.0 ini memiliki sasaran pendidikan dalam menghadapi tantangan yang baru, dengan dukungan dari para profesional oleh digitalisasi khususnya internet dan komputer sebagai bagian dinamika di pendidikan yang memiliki konsep pembelajaran dengan mengedepankan peningkatan kemampuan dalam penguasaan penggunaan laptop sebagai dasar dalam pengembangan perwira siswa dalam mengelola tugas-tugas yang dibebankan kepadanya. Sejauh ini setiap perwira siswa telah mempersiapkan sebelum kegiatan belajar di kampus sekkau dengan terlebih dahulu mengenal akan pembuatan surat dinas, pembuatan slide paparan, dsb yang nantinya akan menjadi kebiasaan ketika ada tugas pembuatan paparan dan naskah akademik.

Penggunaan videotrone pada tahun 2021 lalu telah di pakai pada lembaga Sekkau yang pelaksanaannya sebagai bagian dari penggunaan alins alongin dengan didukung oleh teknologi dalam pemberian materi pelajaran dengan tingkat akurasi dari gambar yang dipancarkan jauh lebih baik daripada dengan menggunakan infokus. Kegunaan ini berdampak pada penerimaan pelajaran oleh perwira siswa dapat berjalan maksimal. Begitu pula dengan program smart kampus telah dikembangkan dan akan dilaksanakan kedepan, dapat memberikan pemahaman yang jelas akan kondisi perlunya para perwira siswa untuk masuk dalam era digitalisasi yang mulai menjadi bagian dalam pengerjaan tugas dan pengiriman tugas serta dalam menggali berbagai buku yang dilakukan secara input digital melalui perpustakaan online. Peran dari lembaga tentang peningkatan ini dengan dukungan dari Komando Pendndikan TNI AU memberikan pemahaman yang serius dari stake holder dalam lingkup pendidikan TNI AU untuk maju bersama memulai sebuuah era baru mencapai terpeliharanya koneksi dengan dunia maya dewasa ini.

Bentuk-bentuk tentang penanganan teknologi di Sekkau ini menjadi suatu harapan baru bagi perkembangan dalam melakukan pendalaman tentang potensi-potensi yang dimiliki oleh perwira siswa untuk melakukan terobosan baru melalui langkah-langkah dalam meningkatkan mutu kualitas pendidikan yang berbasis teknologi dengan diserta adanya suatu pembelajaran yang dapat meningkatkan daya tarik siswa dalam berkreasi untuk merangsang stimulus dalam meningkatkan semangat perwira siswa dan tenaga pendidik untuk lebih mengutamakan pengguaan teknologi bagi berkembangnya nilai-nilai modernisasi. Inovasi baru juga perlu ditingkatkan dalam mengembangkan fasilitas pendidikan guna menyambut datangnya era teknologi sensor reality yang menjadikan peserta didik termotivasi lebih dari sebelumnya.

Penggabungan konsep virtual reality ini adalah adanya penggunaan berbagai jenis aplikasi yang akan disatukan dengan sejenis program melalui teknologi sensor reality sebagai solusi alternatif yang utama khususnya dalam memberikan produk pembelajaran bagi teknologi robotik untuk membentuk jiwa cinta pada penggunaan listrik. Sejaran dari konsep reality virtual ini dibawa sejak 1994 oleh seseorang yang bernama Paul Milgram dan Fumio Kishino yang termuat dalam makalah dengan judul "A Taxonomy of Mixed Reality Visual Displays." Proses pengembangan konsep ini dinamakan dengan virtually continuum yang memiliki peran dalam penyatuan antara suara, ruang dan cahaya dengan dipadu dalam suatu ruang untuk melihat seberapa jelasnya konsep tersebut dilaksanakan bagi perkembangan pola pengajaran kedepan. Contoh seperti dibawah ini adalah contoh gambar yang dapat dipedomani dalam membawa perwira siswa untuk lebih menerapkan teknologi 5.0. 


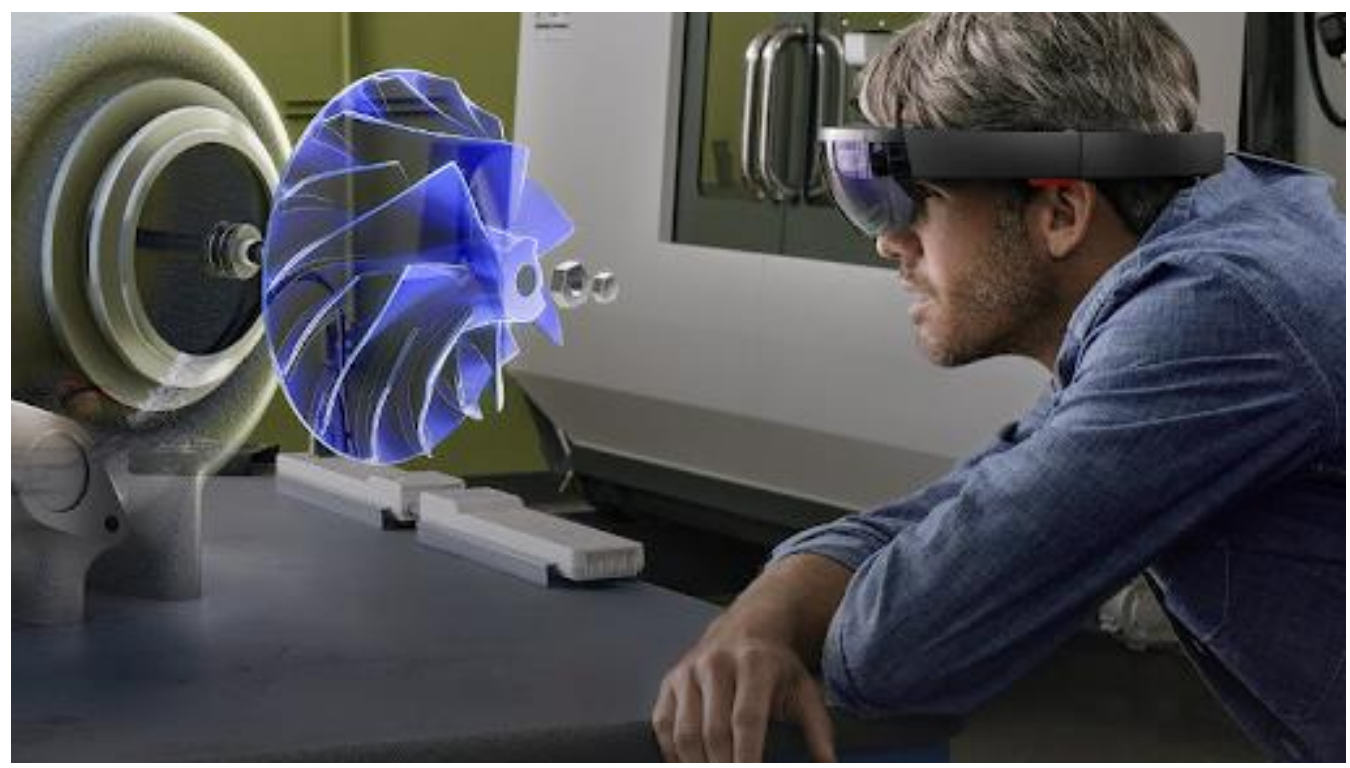

Gambar 2. $\quad$ Engine dengan Virtual reality

Tampak seorang pria mengamati bentuk engine yang dilengkapi dengan konsep virtual reality. Pengertian akan paradigma dengan pola pendidikan virtual ini menambah semangat bagi pengenalan bentuk fisik kedepan dan sesuai dengan yang diharapkan.

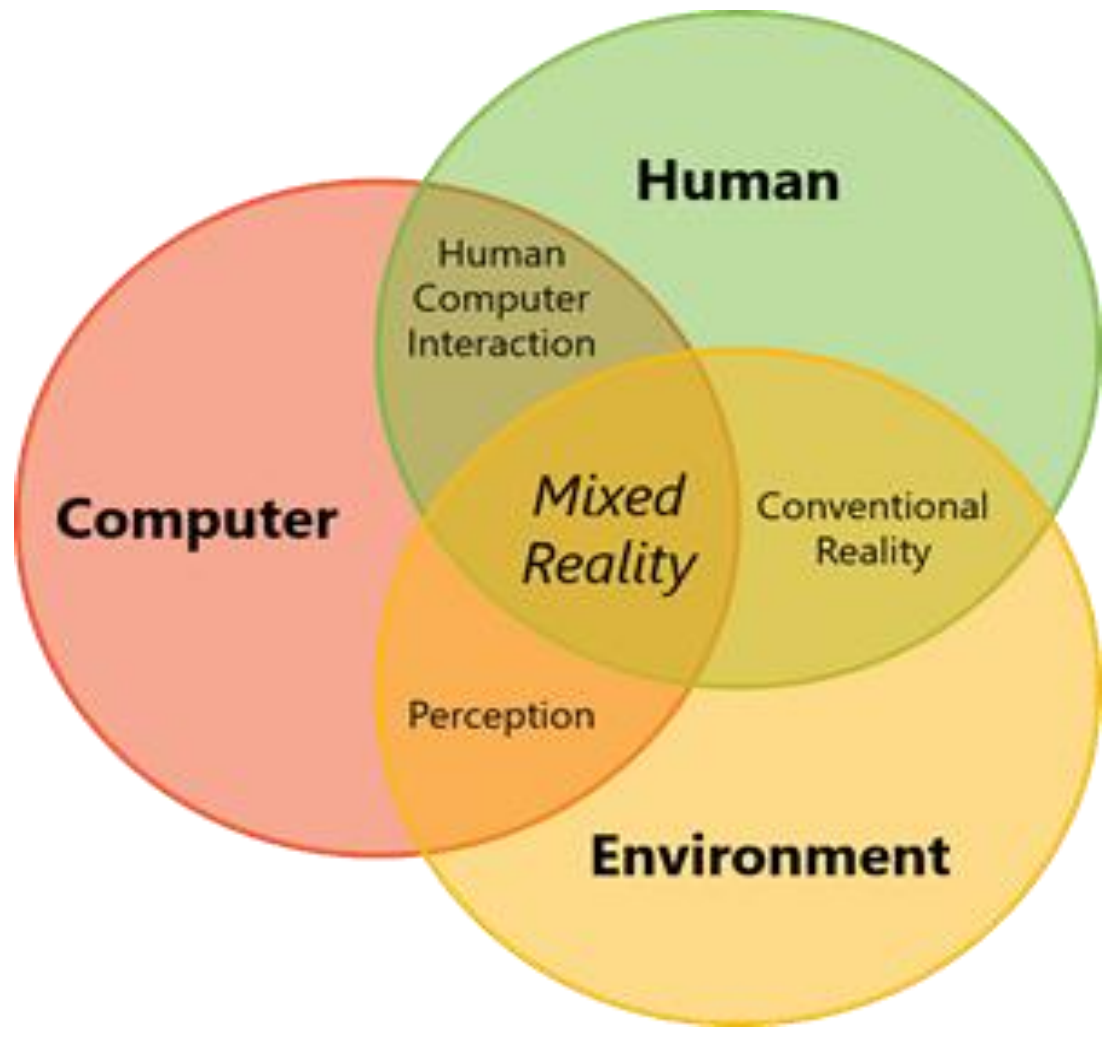

Gambar 3. Diagram Mixed Reality

Diatas ini adalah diagram tentang yang menerangkan tentang bagaimana MR melalui tenaga komputer menggabungkan manusia dan lingkungan. Gambar: Microsoft 
b. Hasil Pelaksanaan Komponen Pendidikan Kedepan. Berbicara tentang hasil yang diinginkan dari keterlibatan pengembangan di era society 5.0 ini memberikan hal-hal yang baru tentunya dalam memberikan mutu pelayanan dalam penyelenggaraan pendidikan saat ini dan masa yang akan datang. Beberapa hal yang memberi dampak cukup kuat dalam perkembangan tersebut adalah sebagai berikut:

1. Fasdik. Identifikasi tentang keberadaan komponen pendidikan seperti adanya dukungan fasilitas pendidikan ini menurut penulis cukup berdampak yang baik dan memberi penilaian yang lebih, khususnya dalam rangka membantu peserta didik dalam menyerap ilmu pengetahuan. Bentuk fasilitas pendidikan ini disebut juga fasdik yang memiliki makna secara langsung bagi alat penunjang dalam proses pendidikan yang diantaranya berupa kondisi gedung pendidikan, adanya jumlah ruang kelas yang disediakan, penggunaan alat-alat seperti media pendidikan, meja kursi dan sebagainya yang menjadi bagian dalam penentuan hasil dari peserta didik saat selesai menyelesaikan pendidikan.

Bagi Lembaga Sekkau ini, untuk fokus pengembangan terhadap kondisi yang dihadapi untuk menunjang kegiatan dalam rangka datangnya era baru society 5.0 telah diantisipas dengan matang melalui suatu perencanaan yang serius dan mendapat respon positif dari pmpinan khususnya Kodiklatau dan Dinas Pendidikan TNI AU. Dengan demikian untuk menunjang permasalahan dalam proses belajar mengajar ini, perlunya tim uji pengembangan yang diketuai oleh beberapa peneliti khususnya dibidang pendidikan dengan standar internasional sehingga pendidikan di Indonesia khususnya di jajaran kedinasan seperti lembaga Sekkau ini dapat menjadi center of excellence yang disegani di kawasan dan memiliki keunggulan SDM yang terdepan di Asia kedepan.

2. Kurikulum. Komponen pendidikan menyebutkan bahwa kurikulum adalah bagian yang tidak dapat terpisahkan dalam upaya penyelenggaraan pendidiakan. Pengembangan kurikulum dilakukan dengan mengacu pada standar nasional pendidikan untuk mewujudkan tujuan pendidikan nasional melalui jenjang dan jenis pendidikan dengan prinsip diversifikasi di satuan pendidikan masing-masing. Kurikulum disusun sesuai dengan jenjang pendidikan menurut kerangka Negara Kesatuan Republik Indonesia dengan memperhatikan iman dan takwa; tuntutan pembangunan daerah dan nasional; dunia kerja; dinamika perkembangan global; dan persatuan nasional serta adanya nilai-nilai kebangsaan yang selalu ditanamkan sebagai upaya untuk menjadikan peserta didik mampu berjiwa Pancasila dan memberi peningkatan di dunia pendidikan dan dunia kerja. Komponen seperti kurikulum ini dalam penyiapan dalam era society 5,0 ini dipersiapkan untuk dikembangkan dengan pengajaran yang berporos pada peningkatan teknologi. Pemanfaatan teknologi digital ini menjadi bagian dalam komponen penddikan seperti pendapat dari P.H. Coombs. Kurikulum berjalan bersama melalui proses penerimaan cepat dan dapat diterima dengan tepat serta dapat menganalisa dengan senang dan berkembang sesuai dengan perancanaan pendidikan yang diinginkannya. Perencanaan ini disesuaikan dengan kondisi tingkatan yang akan diberikan bagi peserta didik. Aspek yang terkandung dalam kurikulum ini memerlukan konsep P21 (Partnership for 21st Century Learning) untuk mengembangkan framework dalam melakukan pembelajaran di abad 21 yang memerlukan keaktifan dari peserta didik agar memiliki berbagai macam keterampilan, pengetahuan dan kemampuan dibidang teknologi, pengetahuan tentang media dan pengolahan informasi, kecakapan tentang keterampilan pembelajaran dan berbagai cara inovasi serta kemampuan tentang hidup dan karir (P21, 2015). Konsep Framework ini juga dapat menjelaskan tentang keterampilan, pengetahuan dan keahlian yang harus dikuasai agar perwira siswa mendapatkan kesuksesan dalam menjalani kehidupan dan pekerjaannya. 


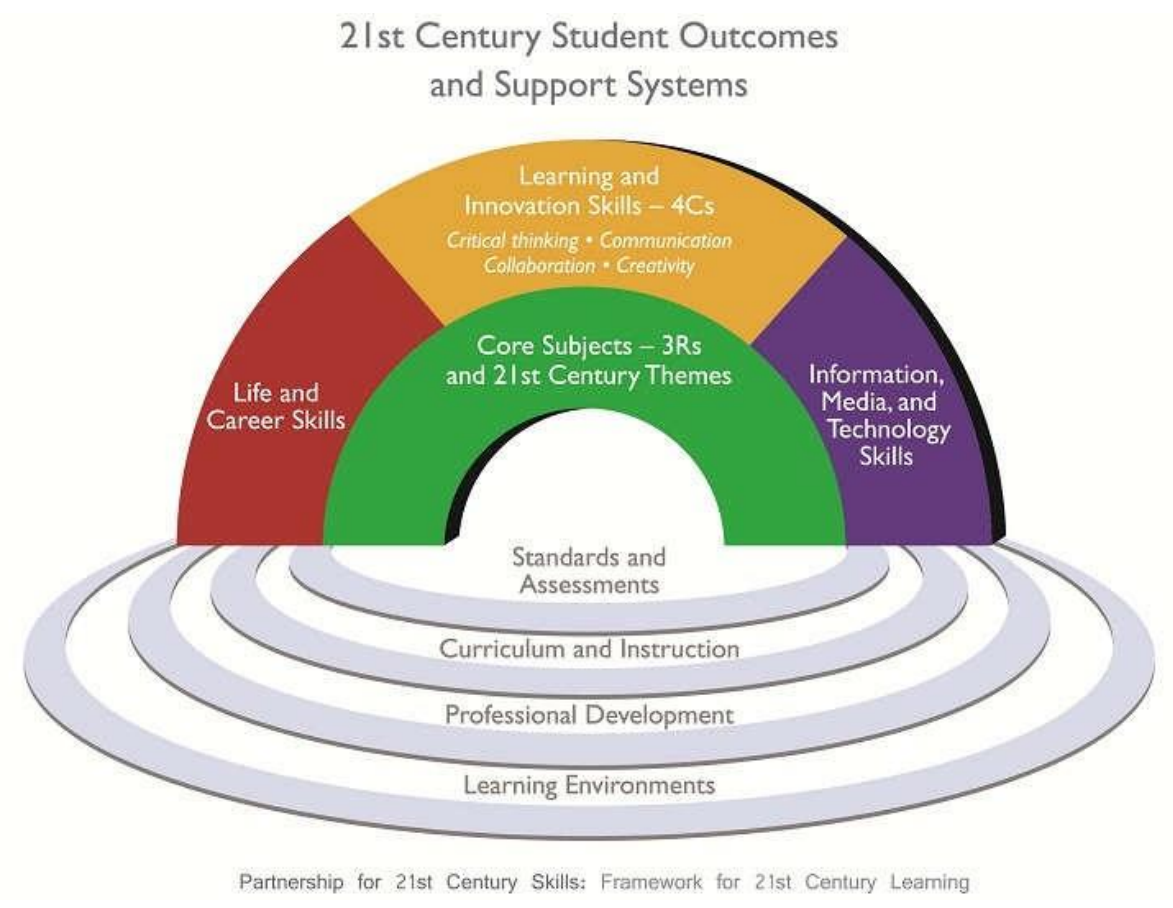

Gambar. 4 Framework Pembelajaran Abad ke-21

Sejalan dengan hal itu, Kemendikbud merumuskan bahwa paradigma pembelajaran abad 21 menekankan pada kemampuan peserta didik dalam mencari tahu dari berbagai sumber, merumuskan permasalahan, berpikir analitis dan kerjasama serta berkolaborasi dalam menyelesaikan masalah (Litbang Kemdikbud, 2013).

3. Serdik. Peserta didik adalah anggota masyarakat yang berusaha mengembangkan potensi diri melalui proses pembelajaran yang tersedia pada jalur, jenjang, dan jenis pendidikan tertentu. Melalui pembahasan ini peseta didik seperti didalam pasal 12 (2) memberikan penekanan bahwa setiap peserta didik berkewajiban: a. menjaga norma-norma pendidikan untuk menjamin keberlangsungan proses dan keberhasilan pendidikan. Dari pengertian ini, maka pentingnya untuk penyelenggarakan pendidikan dengan memperhatikan kondisi dari peserta didik, seperti lulus tes kesehatan dan lulus tes akademik dan beberapa prasyarat lainnya yang berpartisipasi dalam pengembangan perkuliahan pendidikan di Sekkau. Hal ini tidak dapat dipungkiri akan pentingnya menjaga kondisi mental psikologis dan kondisi seperti jantung dan tekanan darah juga memicu adanya permasalahan yang dapat merenggut nyawa peserta didik. Seperti adanya peserta didik yang sakit dan meninggal dunia saat mengikuti pendidikan. Faktor kesehatan juga cukup mendominasi dari pengembangan peningkatan proses penyelenggaraan pendidikan pada umumnya. Oleh karena itu pendampingan bagi perwira siswa yang kurang dari perwira psikologi sangat penting, bahkan memberikan dukungan bagi peningkatan kualitas peserta didik ketika mengalami nilai yang kurang dari cukup (mati). Kondisi ini perlu untuk disingkapi dengan keaktifan dari dosen kelompok dan pihak korsis untuk lebih waspada dalam memberikan penekanan pada peserta didik. Demikian pula terhadap pembinaan kerohanian yang diwajibkan untuk diikuti oleh peserta didik, hal ini menjadi bagian untuk memberi rasa tenang dan tidak mudah menyerah dalam menjalani pendidikan di Sekkau. Sentuhan iman melalui firman Tuhan yang diberikan di tiap-tiap tempat peribadatan menunjang daripada moral peserta didik dalam melakukan pembelajaran di kampus masing-masing tempat, khususnya di Sekkau. Penulis mengharapkan agar peserta didik dapat lebih aktif dalam menanggapi setiap pertanyaan yang dilontarkan 
dosen dan lebih memberikan fokus serta penalaran yang panjang akan kondisi dari perkuliahan di beberapa materi pelajaran seperti operasi udara, kepemimpinan dsb. Prinsip yang kuat dan analisis yang dalam dapat menjadikan lulusan peserta didik menjadi pemimpin yang sanggup menghadapi permasalahan di era society 5.0.

4. Gadik/Pendidik. Pendidik disebut juga dalam keprofesian sebagai dosen penuntun (dostun) merupakan pemberi perhatain dan materi bagi kelangsungan penyelenggaraan pendidikan, karena aktifitasnya yang perlu dibahas dan diberi penekanan khusus untuk kemajuan lembaga pendidikan pada umumnya. Hal ini juga menjadi perhatian oleh Direktur Organisasi dan Sumberdaya Manusia UII (DOSDM), Yulianti Dwi Astuti, S.Psi., M.Soc.Sc.bahwa profesi dosen sebagai pendidik merupakan bagian dari kemampuan yang dimiliki ketika mengajar dan menyampaikan materi di depan kelas. Profesi dosen pada hakikatnya bukanlah sekedar profesi yang dijalankan sebagai sarana mencari rezeki, hanya ingin sekedar menjalankan dinas saja karena banyaknya jabatan yang telah terpenuhi sehingga mendapatkan surat perintah di Lembaga Pendidikan saja. Namun demikian profesi dosen adalah sosok yang dituntut untuk memberikan komitmen dan dedikasi penuh pada bidang ilmu yang dikuasainya. Sosok dari pengabdian dosen ini akan menghasilkan ilmu pengetahuan yang dapat bermanfaat bagi peserta didik dan juga dapat memberikan inspirasi kepada orang-orang di sekitarnya.. Pemegang materi sudah semestinya memiliki pengalaman mengajar dan mempunyai kemampuan yang lebih, karena itu diperlukan orientasi dan standarisasi serta program pertukaran dosen baik di lingkungan TNI AU maupun dilingkup internasional agar program peningkatan mutu pendidik dapat berjalan secara maksimal. Seorang dosen seharusnya memiliki bagian dalam perubahan dan adaptasi, khususnya bagi dosen baru sudah sewajarnya untuk menyaiapkan diri dalam proses penyelenggaraan pendidikan guna mendukung tugas seorang dosen. Selain itu profesi dosen memiliki mental yang baik, dan tidak ada rasa terpaksa dalam menjalankan profesi sebagai dosen. Sebagaimana tuntutan di era 5.0, oleh karena peserta didik banyak yang memiliki gelar S2 dan rata-rata memiliki gelar S1, maka agar menjadi bagian dalam peningkatan mutu kualitas pendidikan dan pengajaran, agar kompetensi seorang dosen untuk setingkat pendidikan Sekkau, agar minimal memiliki gelar S2 bahkan S3. Selanjutnya dalam rangka dapat memberikan pengalaman dalam memberikan materi pelajaran tersebut, agar kualifikasi seorang dosen diharapkan untuk memiliki pengalaman sebagai komandan satuan yang dapat menceritakan dan memberikan gambaran akan pentingnya untuk transfer teknologi dan transfer pengalaman dalam kedinasan. Inovasi-inovasi yang baru perlu dikembangkan dengan taktik dan teknik pengajaran yang perlu dimiliki oleh seorang dosen sebagai pendidik, hal ini diperlihatkan dalam esensi ilmu pengetahuan sebagai bagian dalam kemajuan bangsa dan proses dari pemberian daya cipta yang perlu untuk tumbuh dan berkembang di setiap perintah kedinasan satuan dimana seorang prajurit itu ditempatkan.

\section{KESIMPULAN}

1. Peranan Lembaga Pendidikan di era Society 5.0 membawa peserta didik untuk mampu menyelesaikan berbagai tuntutan dari tantangan yang datang melalui keterlibatannya dalam berbagai inovasi seperti Internet of Things (internet untuk segala sesuatu), Artificial Intelligence (kecerdasan buatan), Big Data (data dalam jumlah besar), dan penggunaan robot untuk meningkatkan kualitas hidup manusia sebagai bagian dari kemajuan teknologi, khususnya dalam pengerjaan dalam penyelesaian tugas-tugas pendidikan yang didukung oleh teknologi sebagai komponen pendidikan bagi penyiapan peserta didik untuk meningkatkan skill dan kompetensi di kehidupan dan karier kedepan. 
2. Peran lembaga di Sekkau dalam menyiapkan berbagai hal yang termasuk dalam komponen pendidikan seperti kesiapan fasilitas pendidikan, kesiapan pengembangan kurikulum yang ada, kesiapan penyelenggara sumber daya manusia (SDM), alins/alongin yang berperspektif pada society 5.0, dan tahapan untuk meningkatkan kualitas hasil peserta didik yang unggul dan berwawasan kedepan dengan dilengkapi berbagai pengembangan seperti pengembangan SDM, pengembangan kurikulum, dan diperlengkapi kompetensi dan inovasi para dosen untuk dapat meningkatkan kualitas peserta didik dalam pembelajaran pendidikan.

3. Hasil dari pengembangan komponen pendidikan kedepan adalah tercapainya tujuan pendidikan seiiring dengan sasaran dan startegi pendidikan yang telah direncanakan dengan melakukan berbagai evaluasi yang diantaranya melibatkan fasilitas pendidikan (fasdik), gadik (tenaga pendidikan), pengembangan kurikulum dan kondisi peserta didik yang dapat mengikuti pendidikan dengan senang, tenang, dapat mengerti paparan yang diberikan dosen serta sanggup melakukan perubahan baik dalam analisa maupun dalam aplikasi dan memiliki inovasi yang dapat meningkatkan SDM individu dengan baik, yang kesemuanya itu dapat menjadikan teladan bagi lingkungan dan pekerjaan di tempat masing-masing.

\section{UCAPAN TERIMA KASIH}

Ucapan terimakasih kami persembahkan kepada Gubernur Akademi Angkatan Udara yang telah mengijinkan terselenggaranya Seminar Nasional AAU tahub 2021 sehinnga kami dapat menyusun penelitian ini denga sebaik-baiknya. Tak lupa ucapan yang sama kepada seluruh panitia seminar yang telah menyusun kegiatan seminar dengan sangat baik disamping tugas-tugas pokok yang harus dikerjakan.

Selanjutnya ucapan terima kasih kepada tim penyusun naskah penelitian ini sehingga dapat terbit pada Seminar Nasional Sains Teknologi dan Inovasi Indonesia 2021 sebagai bagian kolaborasi/kerjasama penelitian antara lembaga pendidikan Sekkau dengan Akademi Angkatan Udara, dengan harapan dapat menambah wawasan dan cakrawala keilmuan bagi Dosen, Gadik, Taruna dan Siswa pada kedua lembaga pendidikan tersebut sehingga meningkatkan kualitas hasil didik dalam menyongsong era Society 5.0 ini.

\section{REFERENSI}

[1] Kurniawan Adi Santoso,Pendidikan untuk menyambut masyarakat 5.0, https://www.alinea.id/kolom/pendidikan-untuk-menyambut-masyarakat-5-0-b1XcI9ijL diambil pada tanggal 26 Oktober 2021.

[2] Keputusan Panglima TNI Nomor Kep/716/X/2012 Tanggal 16 Oktober 2012 tentang Buku Petunjuk Teknis Penyelenggaraan Pendidikan Di Lingkungan TNI.

[3] The World Educational Crisis. A System Analisis. By P.H. Coombs.New York and London: Oxfort University Pres, 1968.

[4] Pasal 3 Undang-undang No. 20 Tahun 2003 tentang Sistem Pendidikan Nasional.

[5] Leon A. Abdilah, Aplikasi Teknologi Informasi: Konsepdan Penerapannya. Medan: Yayasan Kita Menulis. hlm. 61.

[6] Konsep Juknis Opsdik di Lingkungan TNI AU, berdasarkan Surat Perintah Kasau No. Sprin/309/III/2021 tgl. 12 Maret 2021 ttg Pokja Penyusunan Juknis Opsdik di Linkungan TNI AU.

[7] Keputusan Kepala Staf Angkatan Udara Nomor Kep/186/VI/2021 tentang Kurikulum Pendidikan Sekkau.

[8] Undang-undang No. 20 tahun 2003 tentang Sistem Pendidikan Nasional. 
[9] Dr. Ir. Ketut Suriasih, M.App.Sc, Pendidikan Dan Teknologi Era Society 5.0, Rektor Bali Dwipa University, https://www.balipost.com/news/2021/07/06/202591/Pendidikan-dan- Teknologi-di-Era...html ,Diambil pada tanggal 27 Oktober 2021.

[10] Novrisa Wulandari, Mengenal Mixed Reality dan Prediksi Penerapannya di Indonesia, https://www.smarteye.id/blog/mengenal-mixed-reality-dan-penerapannya/, Diambil pada tanggal 27 Oktober 2021.

[11] Konsep Petunjuk Referensi Standarisasi Fasilitas Pendidikan Dan Latihan TNI AU, melalui Surat Perintah Dankodiklatau Nomor Sprin/1409/X.2021 tanggal 29 Oktober 2021 ttg penyusunan draft petunjuk standarisasi fasilitas pendidikandi lingkungan TNI AU.

[12] Pasal 36 (1) UU no. 20 tahun 2003 ttg Sistem Pendidikan Nasional.

[13] Estika Yuni, Dwi Agus Sudjiman, Amat Nyoto, Transformasi Pendidikan Abad 21 Sebagai Tuntutan Pengembangan Sumber Daya Manusia Di Era Global, Volume! Tahun 2016, Universitas Negeri Malang, hlm. 4.

[14] Undang-undang No. 20 Tahun 2003 tentang Sistem Pendidikan Nasional, hlm. 5.

[15] Yulianti Dwi Astuti, S.Psi., M.Soc.Sc, Profesi Dosen Membutuhkan Dedikasi Dan Komitmen, https://www.uii.ac.id/profesi-dosen-membutuhkan-komitmen-dan-dedikasi/, Diambil pada tanggal 3 Nopember 2021 